\title{
Implementation of online foreign language teaching for students of non-linguistic specialties through the Skyes University training platform at North-Eastern Federal University
}

\author{
Oksana S. Nogovitsyna*, Maria $V$. Kulakovskaya \\ North-Eastern Federal University, 58, Belinskiy St., Yakutsk, 677000, Russia
}

\begin{abstract}
The forced transition to distance learning contributed to the rapid development of online learning and the active implementation of educational platforms in the educational process. The previously free choice of online education or mixed formats in a pandemic is being replaced by forced online education. This article examines the process of implementing online foreign language teaching for students of non-linguistic specialties through the Skyes University learning platform. The Institute of Modern Languages and International Studies of the North-Eastern Federal University began teaching 1st year students of non-linguistic specialties English through the Skyes digital learning platform (DLP). Skyes University's digital learning environment contains a large number of regularly updated training courses. The purpose of this training is to develop the communicative competence of students of nonlinguistic specialties. The article provides an overview of the scientific works of domestic and foreign researchers in the field of e-learning. The concepts of "online learning" and "distance learning" have been clarified. The analysis of the digital educational environment of Skyes University was carried out and the possibilities of implementing online English language teaching for students of non-linguistic specialties in a higher educational institution were considered. Conclusions are made based on the analysis of the digital educational environment of Skyes University as part of the implementation of online education at NorthEastern Federal University.
\end{abstract}

\section{Introduction}

At the end of March 2020, the main goal was set for educational institutions - to provide the opportunity to conduct classes remotely in connection with the onset of the pandemic. As a result of the COVID-19 pandemic, there have been changes in the economy, culture and education.

The forced transition to distance learning contributed to the rapid development of online learning and the active implementation of educational platforms in the educational process. The previously free choice of online education or mixed formats in a pandemic was being replaced by forced online education.

\section{Materials and methods}

The purpose of the study is to analyze the digital educational environment of Skyes University and consider the possibility of implementing online teaching English to students of non-linguistic specialties in a higher educational institution.

The object of the research is the process of online teaching English for students of non-linguistic specialties at a federal university, carried out on the basis of Skyes University.

\section{Literature review}

The term "e-learning" has been a subject of controversy and debate among domestic and foreign researchers for a long time. A study of the available scientific works showed that among the studies in the field of online education, there is no uniformity in the application of the terminological glossary.

As A.A. Strizhenko notes, the key terms most applied by researchers include: e-learning, online-learning, distance learning [12].

A.S. Fomina defines online learning as an Internetbased method of organizing independent study of educational materials using an educational environment, as well as training on the Internet using multimedia tools.

T. Mayes believes that the essence of e-learning is teaching and learning, based on information technology [21]. The French researcher R. Andrews believes that the use of any electronic media in all types of teaching and learning turns learning into electronic, and this applies to learning both on the Internet and outside it [19]. A. Pange and J. Pange define the concept of e-learning as a process of knowledge formation and improving the quality of education, noting that learning is carried out through the Internet [17]. 
Foreign researchers J. Moore, Dixon-Deane, Galyen Krista distinguish between the deep meaning and definition of "e-learning and online-learning. They believe that the goals of training, its planned outcome, the type of training content and access determine the design of the educational space of higher education. Moreover, the type of access can be either physical, virtual or mixed [18].

According to N.V. Grechushkin, an e-learning system is that software product accessible via the Internet or another local network by login and password. [11].

N.Kh Gafiatulina et al. note that in the scientific literature researchers do not differentiate the concepts of "remote" and "electronic", considering them to be synonyms. However, as the theoretical and practical analysis of scientific socio-pedagogical literature shows, this is not correct, as evidenced by article 16 of the Federal Law "On education in the Russian Federation" of December 29, 2012 [12].

I.R. Gafurov et al. believe that the terms "distance learning" and "online learning" are not the same. Researchers understand distance learning as learning in which the teacher, in one way or another, including by mail, sends or sends assignments and checks and is at a distance with the student. T.A. Dalgaly notes that online learning and distance learning have the same tools. The researcher further explains that in online learning, knowledge and skills are acquired using devices connected to the Internet online [14]. Distance learning involves distance between student and teacher. L.V. Pushkareva, who distinguishes such forms of online learning as online lectures, on-distance learning believes that "online learning and distance learning are different forms of organizing the learning space" [15].

According to A.V. Lubsky and V.V. Kovalev, online learning and distance learning are different forms of organizing the educational process in the educational space of the university. For both forms of education, the basis is information and communication technologies, thanks to which "their learning spaces are virtual, i.e. act as imitation analogs that simulate reality" [3].

A.A. Strizhenko believes that "when it comes to the use of the Internet and the World Wide Web, it is logical to refer to the terms e-learning and online-learning, and distance learning is of a general nature" [2].
Online lesson is one of the forms of distance learning according to T.A. Dyakova and other domestic researchers who regard it as the main organizational component of online learning. They suggest that an online lesson is also an independent linguodidactic definition of a digital educational space and a form of distance learning with direct communication between a teacher and a student in real time using IP-telephony technology. As a result, the concepts of "distance learning" and "online learning" are different and are not identical [14]. A.A. Zankova classifies online courses from the standpoint of organizing training with the participation of a teacher and without his participation, that is, in a synchronous or asynchronous communication mode [1].

N.Kh. Gafiatulina and others emphasize that in the distance learning format, the interaction of the subjects of the educational space is asynchronous, where the main role is assigned to the student, who can reproduce the learning space at any convenient time. [12].

Summing up, we can say that online learning is an innovative way of delivering education and educational resources to students, contributing to the development of a new culture of learning, communication, cooperation, knowledge acquisition via the Internet, and the creation of networked academic communities [12].

\section{Results}

The Department of Foreign Languages for the Humanities and the Department of Foreign Languages for Technical and Natural sciences of The Institute of Modern Languages and International Studies of NorthEastern Federal University in the 2021-2022 academic year began to implement intensively modularization of 1st year students in English through the Skyes digital learning platform (DLP). The purpose of this training is to develop the communicative competence of students of non-linguistic specialties. The training takes place in two stages: DLP

- extracurricular training through Skyes University

- classroom training / online training through videoconferencing app ZOOM.

Table 1. Educational process of 1st year bachelor students in the 2021 - 2022 academic year

\begin{tabular}{|c|c|c|c|c|c|c|}
\hline \multicolumn{6}{|c|}{ Extract from working curriculum (144 hours) } & \multirow{2}{*}{$\begin{array}{c}\text { Student Self- } \\
\text { Study Work } \\
\text { Skyes Uni }\end{array}$} \\
\hline Semester & $\begin{array}{c}\text { Classroom lessons } \\
\text { [hours] }\end{array}$ & $\begin{array}{c}\text { Number of hours } \\
\text { per week }\end{array}$ & $\begin{array}{c}\text { Number of } \\
\text { hours per } \\
\text { day }\end{array}$ & $\begin{array}{l}\text { Number of } \\
\text { weeks }\end{array}$ & $\begin{array}{l}\text { Number of } \\
\text { months }\end{array}$ & \\
\hline 1 & 60 & 10 & 2 & 6 & 1,5 & 11 \\
\hline 2 & 84 & 10 & 2 & 8,4 & 2,1 & 23 \\
\hline
\end{tabular}


Table 2. Training schedule

\begin{tabular}{|c|c|c|c|c|c|c|c|}
\hline September & October & November & December & February & March & April & May \\
\hline $\begin{array}{c}\text { Auditory } \\
\text { lessons }\end{array}$ & $\begin{array}{c}\text { Auditory } \\
\text { lessons }\end{array}$ & $\begin{array}{c}\text { Student } \\
\text { Self-Study } \\
\text { Work } \\
\text { Skyes Uni }\end{array}$ & $\begin{array}{c}\text { Auditory } \\
\text { lessons }\end{array}$ & $\begin{array}{c}\text { Auditory } \\
\text { lessons }\end{array}$ & $\begin{array}{c}\text { Auditory } \\
\text { lessons }\end{array}$ & $\begin{array}{c}\text { Student } \\
\text { Self-Study } \\
\text { Work } \\
\text { Skyes Uni }\end{array}$ & $\begin{array}{c}\text { Student } \\
\text { Self- } \\
\text { Study } \\
\text { Work } \\
\text { Skyes } \\
\text { Uni }\end{array}$ \\
\hline
\end{tabular}

Thus, classroom lessons are conducted daily for 2 academic hours for 1.5-2 months according to the Working Curriculum.

At the beginning of the school year, an entrance test was conducted to determine the level of English proficiency. According to the test results, students were divided into groups with the level of proficiency A1, A2, B1. The ExtraPractice course is designed for the following levels of English proficiency, which are A0 32 hours, B1 - 46 hours, B2 - 38 hours, C1 - 32 hours of student's independent work on the platform. At a nonlinguistic institution, students' English proficiency at admission rarely exceeds A2. In this regard, students worked on this platform for the ExtraPractice training course, level A0. This course contains additional materials on General English and coincides with the subject of the work programs of the "Foreign Language" discipline for all areas of training for bachelors.
After registering in the personal account, the teacher creates a group. Each group has a group code by which students register independently. The teacher sends assignments to students from his personal account. The material is presented in a structured manner, there is a built-in audio English-Russian dictionary and a system for automatic checking and grading of assignments. Assessment is carried out on a 10-point scale for each task and Unit, and the total score is displayed in the statement during the entire training period. We would like to note that there are different interfaces on the site and in the application and the way of presenting material is different. In the application, the student is offered life situations such as Travel, Make connections, Chat easily, online activities for inspiration, video practice, audio books, daily learning of new words.

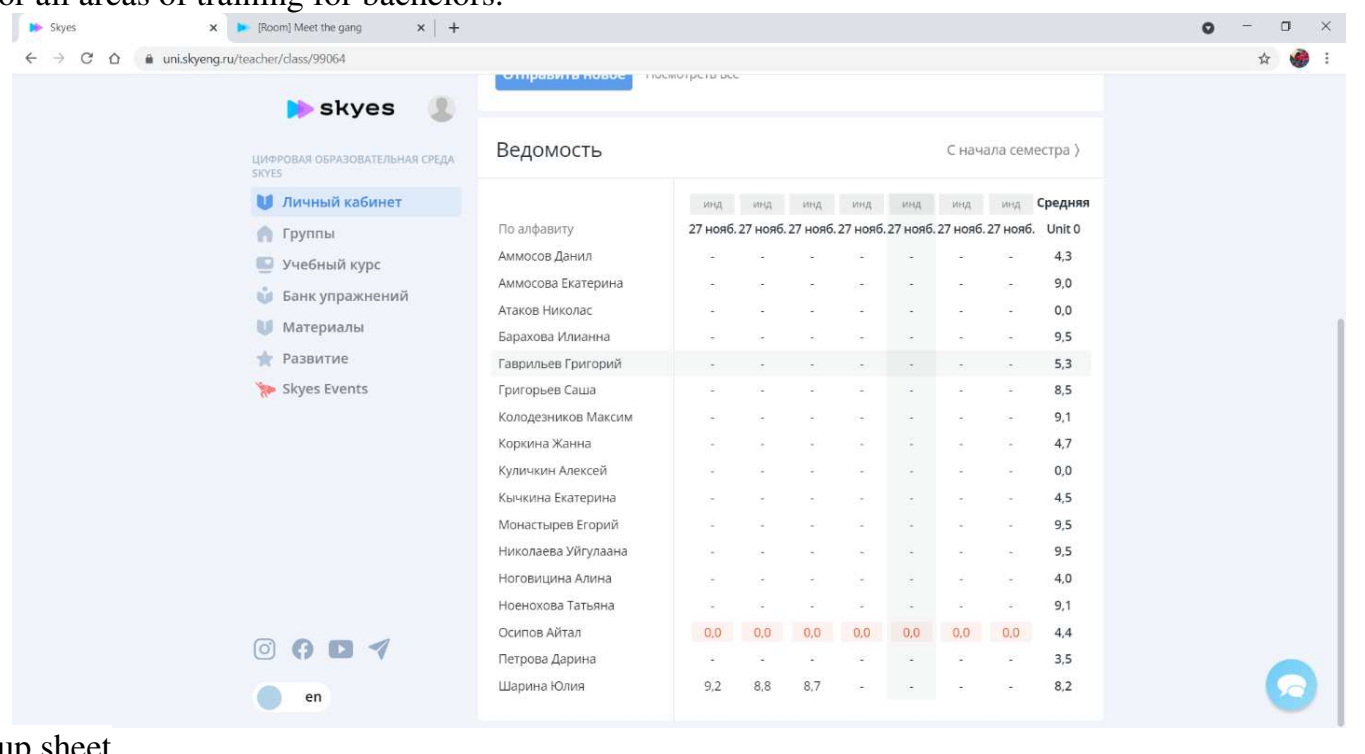

Fig. 1. Group sheet

The platform contains audio recordings, with the ability to listen at different speeds, which is important for students with a low level of language proficiency.

Let us consider the Skylike A2 tutorial. This teaching material consists of a textbook, a workbook, which includes 8 sections of 32 lessons, a manual for the teacher, as well as tests: entrance, intermediate and final. This course is designed for 160 academic hours: 64 hours of classroom work and 96 hours of extracurricular work. It was developed in co-authorship with Thomaï Alexiou, $\mathrm{PhD}$ in linguistics, professor at the Aristotle University of Thessaloniki. Thomaï Alexiou is the author of many Cambridge textbooks for public universities in Greece and the UAE. The author claims that the Skylike A2 textbook was created with innovative elements embedded in its design, such as Gardner's Theory of Multiple Intelligences and Bloom's Taxonomy. Thomaï Alexiou set the goal of the textbook to accelerate the development of communication skills and cognitive abilities of students, and included mediation exercises in the course, note that $1 / 4$ of the course is devoted to project activities. There are enough games of various kinds in the training course, which have not only a teaching purpose, but also aimed at creating a favorable atmosphere of easy communication in classroom or online classes with a teacher.. 


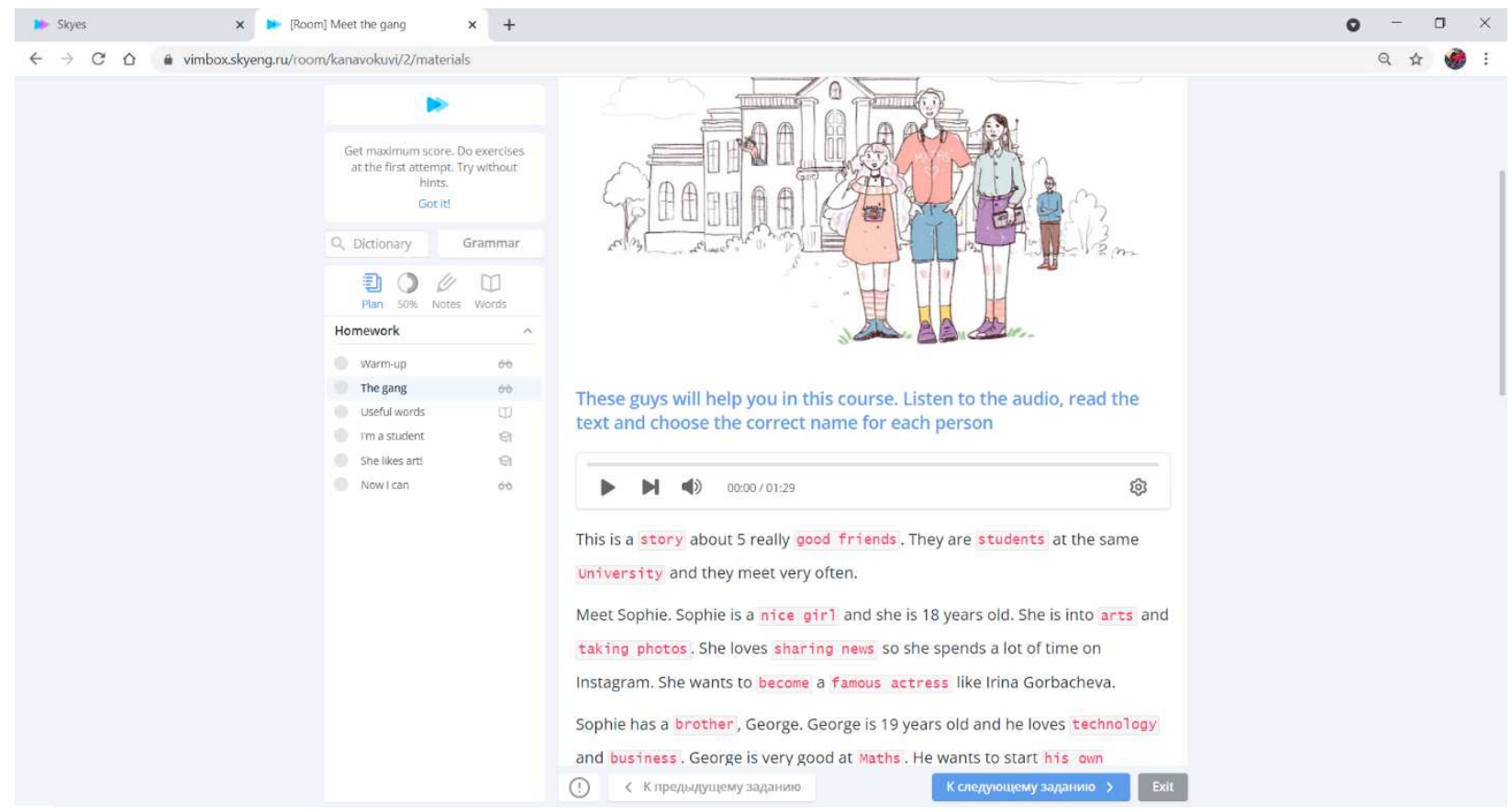

Fig. 2. Audio recording

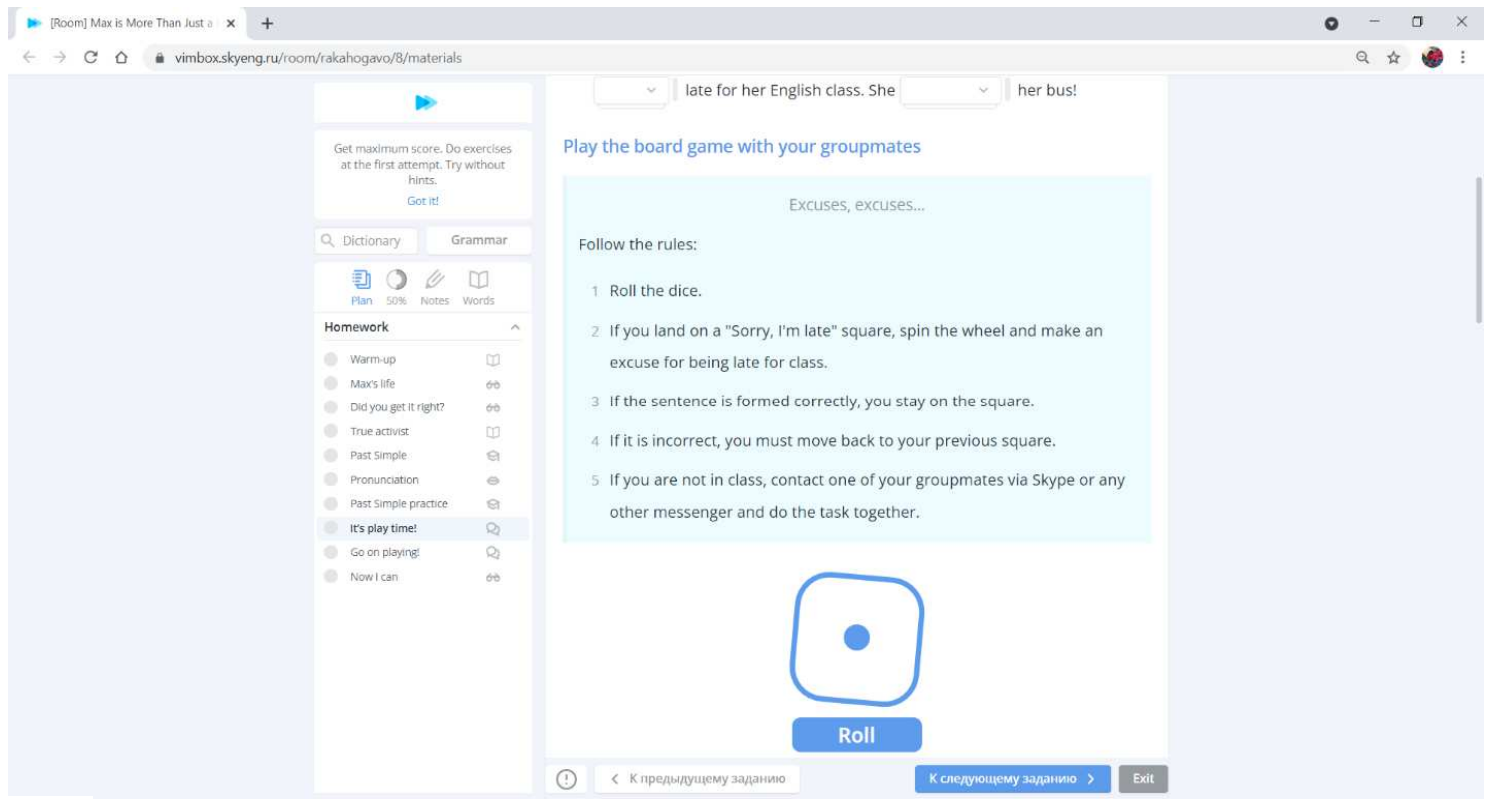

Fig. 3. Game

The digital educational environment of Skyes University, in addition to training courses, offers an Exercise Bank containing short courses on internships abroad, listening videos, lessons and interactive simulators in phonetics, vocabulary and grammar.

Skylike A2 Training and Methodology Complex contains interactive gamified functionality, storyline and protagonists-university students who plan, study and communicate. All this allows you to motivate and involve students in learning English.

On the platform, each student, depending on the points and the number of courses taken, has a rating that motivates students to study and keeps abreast of changes in his rating in the group. Tasks from the teacher come in the form of homework. Also, students can independently study all the training courses provided on the platform, such as SkyCareer (level B1-B2), English for IT (B1B2), Academic Writing (B1-B2).

The main advantage of working at the Skyes University DLP is its mobility, the ability to study anytime, anywhere. Since NEFU students generally do not live in the city itself, but come from the central or northern uluses of the Republic of Sakha (Yakutia), where there is an Internet network, this format of training is most suitable for them. The platform also allows you to work with a multi-level group, when the teacher selects assignments of different complexity for different students, implementing an individual approach to students [6]. 


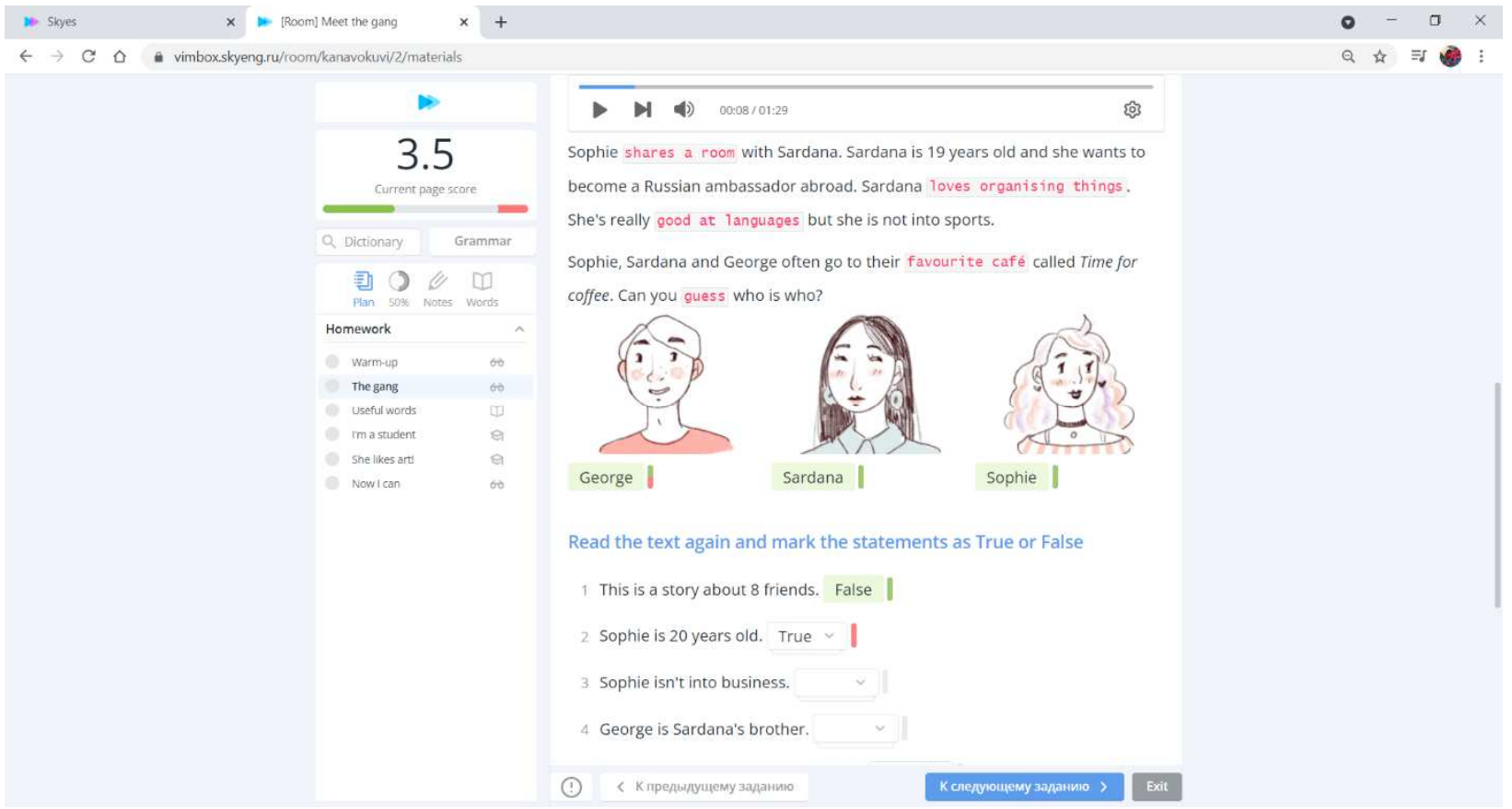

Fig. 4. Characters

\section{Conclusion}

Thus, the forced transition to distance learning contributed to the rapid development of online learning and the active implementation of educational platforms in the educational process. The digital educational environment of Skyes University contains a large number of training courses, regularly updated and contributes to the development of not only communicative competence, but currently relevant soft skills, critical thinking.

\section{References}

1. A.A. Zankova. Learning Russian as a foreign language in the online environment: opportunities and specifics World of Science, Culture and Education. 2 (75), 28-29 (2019)

2. A.A. Strizhenko. Online education: theory and practice Economics. Profession. Business. 75-79 (2016)

3. A.V. Lubsky. V.V. Kovalev From "onlineization" of higher education to online education Humanitarian of the South of Russia. 2, 33-50 (2020)

4. A.S. Fomina. Online learning in a higher educational institution: methods, content, technologies Society: sociology, psychology, pedagogy. 1,101-106 (2016)

5. A.Yu. Leibovsky, N.G. Ivanova, L.N. Porubayko. Pros and cons of the new format of the educational process in Russian universities in the transition to distance learning in selfisolation mode. Theory and practice of physical culture. In search of a new breakthrough. 9, 110-112 (2021)
6. D.Yu. Burenkova How to create an effective learning environment using advanced innovative technologies in English lessons in higher educational institutions. Baltic Humanitarian Journal., 2 (35), 51-54 (2021)

7. 7.E. G. Belyakova Online training: In statu nascendi. Vocational education and the labor market. 2, 45-46 (2020)

8. E.N. Strelchuk. Prospects for online teaching Russian as a foreign language in Russian universities Rusistika19(1), 102-105 (2021)

9. I.R. Gafurov, Ibragimov G.I., Kalimullin A.M., Alishev T.B. Transforming Higher Education During a Pandemic: Pain Points. Higher education in Russia. 10, 101-107 (2020)

10. M.P. Kozyreva. Blended learning technology for foreign language students - philologists. Bulletin of the Samara University. History, pedagogy, philology. 27 (1), 39-45 (2021) DOI: http://doi.org/10.18287/2542-0445-2021-27-139-45.

11. N.V. Grechushkina Online course: definition and classification Higher education in Russia. 6, 125-134 (2018)

12. N.Kh. Gafiatulina, E.S. Abdulaeva, S.I. Samygin. The specifics of online education in the Russian educational space of higher education. p. 24-28. doi10.23672/t5366-11208847-o

13. T.A. Dalgaty. Online and distance learning: similarities and differences Application of special knowledge in law enforcement and expert activities. (Krasnoyarsk, 2020)

14. T. A. Dyakova, L. E. Khvorova. Online lesson of Russian as a foreign language in the context of digital transformation of pedagogical activity Rusistika. 18(2), 209-219 (2020) 
http://dx.doi.org/10.22363/2618-8163-2020-182-209-219

15. T. I. Ermakova, E. G. Ivashkin. Improving learning technologies that ensure the development of online learning Innovative technologies in educational activities. Materials of the All-Russian Scientific and Methodological Conference. 114-120 (2020)

16. A. Koohang, L. Riley, T. Smith, J. Schreurs. ELearning and Constructivism: from theory to Application Interdisciplinary Journal of ELearning and Learning Objects. 5, 91-109 (2009)

17. A. Pange, J. Pange. Is E-Learning Based on Learning Theories? A Literature Review World Academy of Science, Engeneering and Technology. 5(8), 56-60 (2011)

18. J.L. Moore. D.-D. Camille, G. Krist E-learning, and distance learning environments: are they the same Internet and Higher Education. 14, 129135 (2011)

19. R. Andrews. Does e-Learning Require a New Theory of Learning? Some Initial Thought Journal for Educational Research Online. 3(1), 104-121 (2011)

20. R. Mayer. Coursera Partners 'Conference Keynote Plenary. Newport Beach, CA. (2015), retrieved from:

https://www.coursera.org/learn/courserapartners-portal/lecture/anwb6/richard-mayerkeynote-plenary

21. 21 T. Mayes, S. de Freitas. Review of ELearning Theories, Frameworks and Models. (London: JISC e-Learning Models Desk Study, 2005)

22. 22. Skyes University - Skyes University (Skyeng Education System for University) teaching English at the university. Retrieved from: http://edtek.ru/prod/edcrunch-awardproduct-2020/skyes-university-skyengeducation-system-for-university-prepodavanieangliyskogo-v-vuze 